J Pediatr. 2013 September ; 163(3): 627-630. doi:10.1016/j.jpeds.2013.04.047.

\title{
Acid Suppression and the Risk of Clostridium difficile Infection
}

\author{
Ethan A. Mezoff, M.D. \\ Clinical Fellow Division of Gastroenterology, Hepatology, and Nutrition, Cincinnati Children's \\ Hospital Medical Center
}

Mitchell B. Cohen, M.D. [Professor and Vice-Chair of Pediatrics for Clinical Affairs, Director Division of Gastroenterology, Hepatology, and Nutrition] Cincinnati Children's Hospital Medical Center

"One of the first duties of the physician is to educate the masses not to take medicine."

-Sir William Osler.

Clostridium difficile is a spore-forming gram-positive anaerobic bacillus that infects the gastrointestinal tract causing a spectrum of disease from asymptomatic colonization to lifethreatening toxic megacolon. Morbidity is caused by toxin-mediated disruption of cytoskeletal elements leading to inflammation and cell death. Toxins A and B are the primary toxins produced; only one toxin is required to produce disease and organisms not producing these toxins are considered nonpathogenic. A third, binary toxin, has recently been described although its role in pathogenesis remains unclear (1).

The acquisition of $C$. difficile involves ingestion of the organism in spore or vegetative form, both of which are shed in the feces of those infected at a ratio of about 10:1, respectively (2). The vegetative form may survive on a moist surface for up to 6 hours (2). Whereas the vegetative organism is killed by the acidic gastric environment, the spore form survives $(3,4)$. Having evaded the major passive defense of gastric acid, spores can germinate in the small intestine presumably triggered by the presence of bile salts (5). A suitable colonic environment allows infection (CDI), often leading to $C$ difficile-associated disease (CDAD).

\section{CHANGING EPIDEMIOLOGY}

The last two decades have seen an increase in the incidence of CDAD in the United States and abroad (6-11), and C. difficile has replaced methicillin-resistant Staphylococcus aureus as the most common cause of healthcare-associated infection (12). Adult data have shown a concomitant increase in severity based on mortality and hospitalization rates (13-15). Additionally, an increase in community acquired CDI (CA-CDI) has been observed $(16,17)$.

Pediatric data have shown a similar increase in incidence but not severity (18). A population-based cohort study of CDI in children demonstrated a 12.5 fold increase in

\footnotetext{
(C) 2013 Mosby, Inc. All rights reserved

Publisher's Disclaimer: This is a PDF file of an unedited manuscript that has been accepted for publication. As a service to our customers we are providing this early version of the manuscript. The manuscript will undergo copyediting, typesetting, and review of the resulting proof before it is published in its final citable form. Please note that during the production process errors may be discovered which could affect the content, and all legal disclaimers that apply to the journal pertain.

No conflicts of interest disclosed

The authors declare no conflicts of interest.
} 
incidence over the study period from 2.6 (1991-1997) to 32.6 per 100,000 (2004-2009), adjusted for age and sex (19). Although the incidence of infection may be accurate, the degree of change may be falsely inflated by detection bias with transition to more sensitive PCR based assays during this period. The majority of these cases (75\%) were communityacquired indicating hospital-based studies underestimate the true burden of disease.

The emergence of a hypervirulent strain has contributed to the shifting epidemiologic landscape, but it has not replaced other strains $(20,21)$. Naggie et al analyzed 77 stool samples positive for toxigenic $C$. difficile isolates (22), and found that only 13 (17\%) produced patterns identical to the newly emerged, hypervirulent ribotype 027; in total 19 ribotypes were identified. In fact, the prevalence of hypervirulent CDIs may be decreasing $(23,24)$. Thus, the increase in CDIs cannot simply be attributed to an epidemic strain, but rather the sum of an evolving pathogen and a general increase in host susceptibility and/or risk.

The changes in infection rates and disease behavior have prompted examination of host risk factors for CDI in hopes that risk modification may reduce the burden of disease. Known risk factors include age, sex, antibiotic use, hospitalization or healthcare exposure, gastrointestinal operations, chemotherapy, enteral feeding, and chronic illness. Recently, controversy has surrounded the consideration of acid suppression as a risk for CDI, particularly in the setting of over-the-counter availability and increasing use $(25,26)$. Though the mechanism by which this may occur has not been proven, the increased risk appears biologically plausible.

\section{ACID SUPPRESSION}

Gastric acid suppression is used for conditions such as dyspepsia, gastroesophageal reflux disease, stress ulcer prophylaxis, laryngopharyngeal reflux, duodenal ulceration and $H$. pylori infection. It is accomplished through direct inhibition of the proton pump of gastric parietal cells or indirectly through inhibition by blockage of histamine, the former being more effective at increasing gastric $\mathrm{pH}$. Typical acid secretion creates a gastric $\mathrm{pH}$ of about 1.4 (27). The generally accepted goal of therapy for these conditions, due to observed healing and reduced reflux symptoms, is a gastric $\mathrm{pH}$ at or above 4 (28). Commonly used PPIs achieve this goal $(29,30)$. However, $\mathrm{pH}$ above 4 has been shown to increase bacterial survival, specifically for the spores of Clostridium perfringe, in a mouse model (31). Additionally, in vitro studies have shown PPIs inhibit neutrophil bacteriocidal activity, chemotaxis, and phagocytosis (32-34). Although acid suppression is beneficial for a number of medical conditions, it may place the user at increased risk of enteric infection (35).

\section{ACID SUPPRESSION AND CDI}

Hypochlorhydria was implicated in the transmission of C. difficile as early as 1982 and therapeutic acid suppression was first identified as a risk factor for CDI by Brown, et. al. in $1990(3,36)$. In 2007, Leonard, Marshall, and Moayyedi systematically reviewed 12 papers evaluating 2,948 patients with CDI for previous use of acid suppression (25). They found an increased risk with acid suppression (OR 1.94, 95\% CI 1.37 - 2.75). After separating therapeutic categories, they observed the association was greater for PPI use (OR 1.96, 95\% CI $1.28-3.00)$ than for histamine type 2 receptor antagonist (H2RA) use $(1.40,95 \%$ CI 0.85 - 2.29). Subsequent studies focus on PPI use.

Two meta-analyses have evaluated the association between PPI therapy and risk of CDI in adults. Janarthanan et al performed a systematic literature search of MEDLINE and PubMed databases from 1990 through December 2010 (37). They analyzed studies together and grouped by study design and used a random-effects model to account for heterogeneity 
among studies. Twenty-three studies, including 288,620 hospitalized patients evaluated PPI use for at least the 3 months prior to development of CDAD, found an overall risk ratio of 1.69 (95\% CI, $1.395-1.974)$. When separately analyzed by study type, the risk remained significant. Deshpande et al systematically reviewed the literature between 1990 and 2010 (38). Interestingly, they did not identify one prospective study evaluating PPI use and risk of CDI. They were unsuccessful in obtaining meaningful results from antibiotic use analysis, but they did find an overall increase in risk of CDI with PPI use (OR 2.15 95\% CI, 1.812.55). Subgroup analysis revealed no publication bias. Both studies reported significant heterogeneity.

A recent meta-analysis evaluated incident and recurrent CDI in PPI users as well as the relative impact of concurrent antibiotic use (39). The authors systematically analyzed 42 observational studies ( $\mathrm{N}=313,000$ patients), and found an association between PPI use and risk of CDI (OR 1.74, 95\% CI $1.47-2.85)$ or risk of recurrent CDI (OR 2.51, 95\% CI 1.16 - 5.44). When antibiotics and PPIs were used together, the risk of developing CDI rose above the effect of PPI alone (OR 1.96, 95\% CI $1.03-3.70$ ). An added risk of $19 \%$ was attributed to the interaction between the two drug types, independent of the effect of either drug in isolation. When compared with PPIs, H2RAs carried a lower risk (OR 0.71, 95\% CI $0.53-0.97)$.

Few studies have been conducted to specifically evaluate PPI use as a risk factor for CACDI. Kuntz et al demonstrated the importance of investigating this relationship (40). They found CA-CDI occurring in populations not traditionally thought to be at risk. Twenty-seven percent of subjects with CA-CDI had no antimicrobial exposure 180 days before diagnosis. Exposure to gastric acid suppression was found in $18 \%$ of CA-CDI compared with 5\% of controls (OR 2.30, 95\% CA-CDI) adjusting for antimicrobial use, comorbidity, hospitalizations, age by category ( $<18$ years of age was the reference group), and sex. Eighty-four percent of patients exposed to acid suppression who developed CA-CDI had also received one or more antimicrobial agents.

Heterogeneity in individual study results observed on meta-analysis may indicate a false association, thus it is important to understand the source. Kwok, et. al. used subgroup analysis and the random effects model to evaluate heterogeneity (39). They found a similar association of PPI with risk of CDI in all study methods and a consistent direction of effect indicating a true association. A false association may also be observed with publication bias. Janarthanan, et. al. recognized this potential and demonstrated through trim-and-fill sensitivity analysis that the association was not an artifact of unpublished negative studies (37). Finally, exposure to acid suppression may be under-reported due to its availability as an over-the-counter product. This may lead to an overstatement of risk.

Variables not easily analyzed must also be considered as sources of study heterogeneity. $C$. difficile strain variation may result in regional differences in organism susceptibility to acid or PPI. Furthermore, PPI formulation, brand, and dosing schedule are not generally reported, and these may produce different average intra-gastric $\mathrm{pH}$ values and differing effects on leukocyte function (35). Finally, few studies report dose or frequency though risk may be dose dependent or follow a dose-response curve. Howell, et. al. performed a pharmacoepidemiologic prospective cohort study of 101,796 discharges to evaluate for dose-response (41). After adjusting for age, antibiotic exposure, and propensity score-based likelihood of receiving acid-suppression therapy, they demonstrated increasing acid suppression resulted in an increased risk of CDI. H2RA therapy resulted in an odds ratio of 1.52 (95\% CI, $1.12-2.10$ ). Daily and BID PPI dosing lead to odds ratios of 1.74 (95\% CI, 1.39-2.18) and 2.36 (95\% CI, $1.79-3.11$ ), respectively. The observation of a dose-response supports the role of PPIs as a risk factor in the development of CDI. 


\section{PEDIATRIC STUDIES}

One study has been published that specifically and sufficiently evaluates an association between acid suppression and CDI in hospitalized children (42). This observational, casecontrol study was performed retrospectively on children admitted to the Department of Pediatrics, University of Naples "Federico II" between June 2005 and July 2009. Of 910 children admitted for abdominal pain and diarrhea who underwent testing for CDI, 68 were found to be positive. Controls were selected at random from the remaining 842 patients with a negative stool $C$. difficile toxin assay. The use of PPIs was significantly higher in those testing positive for $C$. difficile toxin (OR 4.52, 95\% CI, 1.4-14.4). A trend toward statistical significance was also found in those using H2RAs but power was not sufficient to statistically confirm association. Notably, antibiotic exposure was not different between groups. On multivariate analysis, IBD and PPI use were associated with CDI.

\section{USE, OVERUSE, AND UNNECCESSARY USE OF PPI}

Use of acid suppression therapy, particularly PPIs, is increasing. Lu, et. al. surveyed the Swedish Prescribed Drug Register and found sales of PPIs (in daily defined doses/1,000 inhabitants/day) increased by over 50\% from 2000 to 2008 (26). Evidence-based guidelines for appropriate use in diverse clinical situations are available (43-47). Overuse occurs when dosing exceeds that which is needed to adequately treat for an appropriate indication. Unnecessary use occurs when acid suppression therapy is prescribed without an appropriate indication.

Unnecessary use and overuse have been well-documented in adults. A study evaluating prescription patterns via pharmacy audit data reviewed ambulatory use in 168,727 adult patients taking PPIs or H2RAs for longer than 90 days (48). This found an appropriate upper GI diagnosis in only $61 \%$ of patients. Heidelbaugh et al studied 946 veterans using PPI therapy and found $36 \%$ had no documented appropriate indication (49). Furthermore, the total cost of inappropriate PPI use was $\$ 1,566,252$. In patients receiving more than daily PPI dosing for an appropriate indication (GERD), step-down to daily dosing or medication discontinuation has been accomplished in some patients without significant relapse of symptoms $(50,51)$. Inpatient overuse and unnecessary use has also been described (52).

\section{RECOMMENDATIONS}

It is biologically plausible that an increase in $\mathrm{pH}$ with a decrease in barrier function of the gastric environment could put one at risk for CDI, and, on February 8, 2012, the FDA released a drug safety communication indicating that PPIs may be associated with an increased risk of CDAD (53). Adult studies confirm that patients undergoing pharmacologic acid suppression are at increased risk of developing CDI; PPI use is associated with an approximately 2 fold increase in risk over non-use, and significantly more risk than H2RA use. Antibiotics appear to act synergistically with PPIs. To date, one study specifically evaluating pediatric risk of CDI with PPI use has shown an increased risk. Further studies in children, particularly in populations at increased risk (IBD, intestinal failure, immunodeficiency) are needed (54). The importance of this grows with the increased incidence of CDI and use of PPIs. Discontinuing acid suppression in patients who need it is not advocated, however, the authors recommend consideration (and documentation) of the expected course of acid suppression when initiating therapy. We also recommend periodic holidays or dosing step-downs to assess continued need in patients who may tolerate such assessment with the understanding that temporary rebound hyperchlorhidria may occur on PPI withdrawal. 


\section{CITATIONS}

1. Kelly CP, LaMont JT. Clostridium difficile--more difficult than ever. The New England journal of medicine. Oct 30; 2008 359(18):1932-40. PubMed PMID: 18971494. [PubMed: 18971494]

2. Jump RL, Pultz MJ, Donskey CJ. Vegetative Clostridium difficile survives in room air on moist surfaces and in gastric contents with reduced acidity: a potential mechanism to explain the association between proton pump inhibitors and C. difficile-associated diarrhea? Antimicrobial agents and chemotherapy. Aug; 2007 51(8):2883-7. PubMed PMID: 17562803. Pubmed Central PMCID: 1932506. [PubMed: 17562803]

3. Gurian L, Ward TT, Katon RM. Possible foodborne transmission in a case of pseudomembranous colitis due to Clostridium difficile: influence of gastrointestinal secretions on Clostridium difficile infection. Gastroenterology. Aug; 1982 83(2):465-9. PubMed PMID: 7084623. [PubMed: 7084623]

4. Rao A, Jump RL, Pultz NJ, Pultz MJ, Donskey CJ. In vitro killing of nosocomial pathogens by acid and acidified nitrite. Antimicrobial agents and chemotherapy. Nov; 2006 50(11):3901-4. PubMed PMID: 17065628. Pubmed Central PMCID: 1635176. [PubMed: 17065628]

5. Wilson KH. Efficiency of various bile salt preparations for stimulation of Clostridium difficile spore germination. Journal of clinical microbiology. Oct; 1983 18(4):1017-9. PubMed PMID: 6630458. Pubmed Central PMCID: 270959. [PubMed: 6630458]

6. Lessa FC, Gould CV, McDonald LC. Current status of Clostridium difficile infection epidemiology. Clinical infectious diseases : an official publication of the Infectious Diseases Society of America. Aug; 2012 55(Suppl 2):S65-70. PubMed PMID: 22752867. Pubmed Central PMCID: 3388017. [PubMed: 22752867]

7. Pepin J, Saheb N, Coulombe MA, Alary ME, Corriveau MP, Authier S, et al. Emergence of fluoroquinolones as the predominant risk factor for Clostridium difficile-associated diarrhea: a cohort study during an epidemic in Quebec. Clinical infectious diseases : an official publication of the Infectious Diseases Society of America. Nov 1; 2005 41(9):1254-60. PubMed PMID: 16206099. [PubMed: 16206099]

8. Kim J, Smathers SA, Prasad P, Leckerman KH, Coffin S, Zaoutis T. Epidemiological features of Clostridium difficile-associated disease among inpatients at children's hospitals in the United States, 2001-2006. Pediatrics. Dec; 2008 122(6):1266-70. PubMed PMID: 19047244. [PubMed: 19047244]

9. Burckhardt F, Friedrich A, Beier D, Eckmanns T. Clostridium difficile surveillance trends, Saxony, Germany. Emerging infectious diseases. Apr; 2008 14(4):691-2. PubMed PMID: 18394306. Pubmed Central PMCID: 2570926. [PubMed: 18394306]

10. Gravel D, Miller M, Simor A, Taylor G, Gardam M, McGeer A, et al. Health care-associated Clostridium difficile infection in adults admitted to acute care hospitals in Canada: a Canadian Nosocomial Infection Surveillance Program Study. Clinical infectious diseases : an official publication of the Infectious Diseases Society of America. Mar 1; 2009 48(5):568-76. PubMed PMID: 19191641. [PubMed: 19191641]

11. Zilberberg MD, Tillotson GS, McDonald C. Clostridium difficile infections among hospitalized children, United States, 1997-2006. Emerging infectious diseases. Apr; 2010 16(4):604-9. PubMed PMID: 20350373. Pubmed Central PMCID: 3363321. [PubMed: 20350373]

12. Miller BA, Chen LF, Sexton DJ, Anderson DJ. Comparison of the burdens of hospital-onset, healthcare facility-associated Clostridium difficile Infection and of healthcare-associated infection due to methicillin-resistant Staphylococcus aureus in community hospitals. Infection control and hospital epidemiology : the official journal of the Society of Hospital Epidemiologists of America. Apr; 2011 32(4):387-90. PubMed PMID: 21460491. [PubMed: 21460491]

13. Redelings MD, Sorvillo F, Mascola L. Increase in Clostridium difficile-related mortality rates, United States, 1999-2004. Emerging infectious diseases. Sep; 2007 13(9):1417-9. PubMed PMID: 18252127. Pubmed Central PMCID: 2857309. [PubMed: 18252127]

14. Ricciardi R, Rothenberger DA, Madoff RD, Baxter NN. Increasing prevalence and severity of Clostridium difficile colitis in hospitalized patients in the United States. Archives of surgery. Jul; 2007 142(7):624-31. discussion 31. PubMed PMID: 17638799. [PubMed: 17638799]

15. Muto CA, Pokrywka M, Shutt K, Mendelsohn AB, Nouri K, Posey K, et al. A large outbreak of Clostridium difficile-associated disease with an unexpected proportion of deaths and colectomies 
at a teaching hospital following increased fluoroquinolone use. Infection control and hospital epidemiology : the official journal of the Society of Hospital Epidemiologists of America. Mar; 2005 26(3):273-80. PubMed PMID: 15796280. [PubMed: 15796280]

16. Kutty PK, Woods CW, Sena AC, Benoit SR, Naggie S, Frederick J, et al. Risk factors for and estimated incidence of community-associated Clostridium difficile infection, North Carolina, USA. Emerging infectious diseases. Feb; 2010 16(2):197-204. PubMed PMID: 20113547. Pubmed Central PMCID: 2958012. [PubMed: 20113547]

17. Khanna S, Pardi DS, Aronson SL, Kammer PP, Orenstein R, St Sauver JL, et al. The epidemiology of community-acquired Clostridium difficile infection: a population-based study. The American journal of gastroenterology. Jan; 2012 107(1):89-95. PubMed PMID: 22108454. Pubmed Central PMCID: 3273904. [PubMed: 22108454]

18. Nylund CM, Goudie A, Garza JM, Fairbrother G, Cohen MB. Clostridium difficile infection in hospitalized children in the United States. Archives of pediatrics \& adolescent medicine. May; 2011 165(5):451-7. PubMed PMID: 21199971. [PubMed: 21199971]

19. Khanna S, Baddour LM, Huskins WC, Kammer PP, Faubion WA, Zinsmeister AR, et al. The Epidemiology of Clostridium difficile Infection in Children: A Population-Based Study. Clinical infectious diseases : an official publication of the Infectious Diseases Society of America. Feb 13.2013 PubMed PMID: 23408679.

20. O'Connor JR, Johnson S, Gerding DN. Clostridium difficile infection caused by the epidemic BI/ NAP1/027 strain. Gastroenterology. May; 2009 136(6):1913-24. PubMed PMID: 19457419. [PubMed: 19457419]

21. McDonald LC, Killgore GE, Thompson A, Owens RC Jr. Kazakova SV, Sambol SP, et al. An epidemic, toxin gene-variant strain of Clostridium difficile. The New England journal of medicine. Dec 8; 2005 353(23):2433-41. PubMed PMID: 16322603. [PubMed: 16322603]

22. Naggie S, Miller BA, Zuzak KB, Pence BW, Mayo AJ, Nicholson BP, et al. A case-control study of community-associated Clostridium difficile infection: no role for proton pump inhibitors. The American journal of medicine. Mar; 2011 124(3):276, e1-7. PubMed PMID: 21396512. [PubMed: 21396512]

23. Hensgens MP, Goorhuis A, Notermans DW, van Benthem BH, Kuijper EJ. Decrease of hypervirulent Clostridium difficile PCR ribotype 027 in the Netherlands. Euro surveillance : bulletin europeen sur les maladies transmissibles = European communicable disease bulletin . 2009; 14(45) PubMed PMID: 19941791.

24. Bauer MP, Notermans DW, van Benthem BH, Brazier JS, Wilcox MH, Rupnik M, et al. Clostridium difficile infection in Europe: a hospital-based survey. Lancet. Jan 1; 2011 377(9759): 63-73. PubMed PMID: 21084111. [PubMed: 21084111]

25. Leonard J, Marshall JK, Moayyedi P. Systematic review of the risk of enteric infection in patients taking acid suppression. The American journal of gastroenterology. Sep; 2007 102(9):2047-56. quiz 57. PubMed PMID: 17509031. [PubMed: 17509031]

26. Lu Y, Sverden E, Ljung R, Soderlund C, Lagergren J. Use of non-steroidal anti-inflammatory drugs and proton pump inhibitors in correlation with incidence, recurrence and death of peptic ulcer bleeding: an ecological study. BMJ open. 2013; 3(1) PubMed PMID: 23293249. Pubmed Central PMCID: 3549209.

27. Schubert ML. Gastric secretion. Current opinion in gastroenterology. Nov; 2008 24(6):659-64. PubMed PMID: 19122512. [PubMed: 19122512]

28. Hunt RH, Cederberg C, Dent J, Halter F, Howden C, Marks IN, et al. Optimizing acid suppression for treatment of acid-related diseases. Digestive diseases and sciences. Feb; 1995 40(2 Suppl): 24S-49S. PubMed PMID: 7859582. [PubMed: 7859582]

29. Miner P Jr. Katz PO, Chen Y, Sostek M. Gastric acid control with esomeprazole, lansoprazole, omeprazole, pantoprazole, and rabeprazole: a five-way crossover study. The American journal of gastroenterology. Dec; 2003 98(12):2616-20. PubMed PMID: 14687806. [PubMed: 14687806]

30. Kirchheiner J, Glatt S, Fuhr U, Klotz U, Meineke I, Seufferlein T, et al. Relative potency of proton-pump inhibitors-comparison of effects on intragastric $\mathrm{pH}$. European journal of clinical pharmacology. Jan; 2009 65(1):19-31. PubMed PMID: 18925391. [PubMed: 18925391] 
31. Tennant SM, Hartland EL, Phumoonna T, Lyras D, Rood JI, Robins-Browne RM, et al. Influence of gastric acid on susceptibility to infection with ingested bacterial pathogens. Infection and immunity. Feb; 2008 76(2):639-45. PubMed PMID: 18025100. Pubmed Central PMCID: 2223456. [PubMed: 18025100]

32. Zedtwitz-Liebenstein K, Wenisch C, Patruta S, Parschalk B, Daxbock F, Graninger W. Omeprazole treatment diminishes intra- and extracellular neutrophil reactive oxygen production and bactericidal activity. Critical care medicine. May; 2002 30(5):1118-22. PubMed PMID: 12006811. [PubMed: 12006811]

33. Wandall JH. Effects of omeprazole on neutrophil chemotaxis, super oxide production, degranulation, and translocation of cytochrome b-245. Gut. May; 1992 33(5):617-21. PubMed PMID: 1319381. Pubmed Central PMCID: 1379289. [PubMed: 1319381]

34. Agastya G, West BC, Callahan JM. Omeprazole inhibits phagocytosis and acidification of phagolysosomes of normal human neutrophils in vitro. Immunopharmacology and immunotoxicology. May; 2000 22(2):357-72. PubMed PMID: 10952036. [PubMed: 10952036]

35. Bavishi C, Dupont HL. Systematic review: the use of proton pump inhibitors and increased susceptibility to enteric infection. Alimentary pharmacology \& therapeutics. Dec; 2011 34(11-12): 1269-81. PubMed PMID: 21999643. [PubMed: 21999643]

36. Brown E, Talbot GH, Axelrod P, Provencher M, Hoegg C. Risk factors for Clostridium difficile toxin-associated diarrhea. Infection control and hospital epidemiology : the official journal of the Society of Hospital Epidemiologists of America. Jun; 1990 11(6):283-90. PubMed PMID: 2373850. [PubMed: 2373850]

37. Janarthanan S, Ditah I, Adler DG, Ehrinpreis MN. Clostridium difficile-associated diarrhea and proton pump inhibitor therapy: a meta-analysis. The American journal of gastroenterology. Jul; 2012 107(7):1001-10. PubMed PMID: 22710578. [PubMed: 22710578]

38. Deshpande A, Pant C, Pasupuleti V, Rolston DD, Jain A, Deshpande N, et al. Association between proton pump inhibitor therapy and Clostridium difficile infection in a meta-analysis. Clinical gastroenterology and hepatology : the official clinical practice journal of the American Gastroenterological Association. Mar; 2012 10(3):225-33. PubMed PMID: 22019794. [PubMed: 22019794]

39. Kwok CS, Arthur AK, Anibueze CI, Singh S, Cavallazzi R, Loke YK. Risk of Clostridium difficile infection with acid suppressing drugs and antibiotics: meta-analysis. The American journal of gastroenterology. Jul; 2012 107(7):1011-9. PubMed PMID: 22525304. [PubMed: 22525304]

40. Kuntz JL, Chrischilles EA, Pendergast JF, Herwaldt LA, Polgreen PM. Incidence of and risk factors for community-associated Clostridium difficile infection: a nested case-control study. BMC infectious diseases. 2011; 11:194. PubMed PMID: 21762504. Pubmed Central PMCID: 3154181. [PubMed: 21762504]

41. Howell MD, Novack V, Grgurich P, Soulliard D, Novack L, Pencina M, et al. Iatrogenic gastric acid suppression and the risk of nosocomial Clostridium difficile infection. Archives of internal medicine. May 10; 2010 170(9):784-90. PubMed PMID: 20458086. [PubMed: 20458086]

42. Turco R, Martinelli M, Miele E, Roscetto E, Del Pezzo M, Greco L, et al. Proton pump inhibitors as a risk factor for paediatric Clostridium difficile infection. Alimentary pharmacology \& therapeutics. Apr; 2010 31(7):754-9. PubMed PMID: 20047577. [PubMed: 20047577]

43. Schwartz SR, Cohen SM, Dailey SH, Rosenfeld RM, Deutsch ES, Gillespie MB, et al. Clinical practice guideline: hoarseness (dysphonia). Otolaryngology--head and neck surgery : official journal of American Academy of Otolaryngology-Head and Neck Surgery. Sep; 2009 141(3 Suppl 2):S1-S31. PubMed PMID: 19729111. [PubMed: 19729111]

44. Furuta GT, Liacouras CA, Collins MH, Gupta SK, Justinich C, Putnam PE, et al. Eosinophilic esophagitis in children and adults: a systematic review and consensus recommendations for diagnosis and treatment. Gastroenterology. Oct; 2007 133(4):1342-63. PubMed PMID: 17919504. [PubMed: 17919504]

45. Koletzko S, Jones NL, Goodman KJ, Gold B, Rowland M, Cadranel S, et al. Evidence-based guidelines from ESPGHAN and NASPGHAN for Helicobacter pylori infection in children. Journal of pediatric gastroenterology and nutrition. Aug; 2011 53(2):230-43. PubMed PMID: 21558964. [PubMed: 21558964] 
46. Vandenplas Y, Rudolph CD, Di Lorenzo C, Hassall E, Liptak G, Mazur L, et al. Pediatric gastroesophageal reflux clinical practice guidelines: joint recommendations of the North American Society for Pediatric Gastroenterology, Hepatology, and Nutrition (NASPGHAN) and the European Society for Pediatric Gastroenterology, Hepatology, and Nutrition (ESPGHAN). Journal of pediatric gastroenterology and nutrition. Oct; 2009 49(4):498-547. PubMed PMID: 19745761. [PubMed: 19745761]

47. ASHP Therapeutic Guidelines on Stress Ulcer Prophylaxis. ASHP Commission on Therapeutics and approved by the ASHP Board of Directors on November 14, 1998. American journal of health-system pharmacy : AJHP : official journal of the American Society of Health-System Pharmacists. Feb 15; 1999 56(4):347-79. PubMed PMID: 10690219. [PubMed: 10690219]

48. Jacobson BC, Ferris TG, Shea TL, Mahlis EM, Lee TH, Wang TC. Who is using chronic acid suppression therapy and why? The American journal of gastroenterology. Jan; 2003 98(1):51-8. PubMed PMID: 12526936. [PubMed: 12526936]

49. Heidelbaugh JJ, Goldberg KL, Inadomi JM. Magnitude and economic effect of overuse of antisecretory therapy in the ambulatory care setting. The American journal of managed care. Sep; 2010 16(9):e228-34. PubMed PMID: 21250399. [PubMed: 21250399]

50. Inadomi JM, McIntyre L, Bernard L, Fendrick AM. Step-down from multiple-to single-dose proton pump inhibitors (PPIs): a prospective study of patients with heartburn or acid regurgitation completely relieved with PPIs. The American journal of gastroenterology. Sep; 2003 98(9):19404. PubMed PMID: 14499769. [PubMed: 14499769]

51. Inadomi JM, Jamal R, Murata GH, Hoffman RM, Lavezo LA, Vigil JM, et al. Step-down management of gastroesophageal reflux disease. Gastroenterology. Nov; 2001 121(5):1095-100. PubMed PMID: 11677201. [PubMed: 11677201]

52. Heidelbaugh JJ, Kim AH, Chang R, Walker PC. Overutilization of proton-pump inhibitors: what the clinician needs to know. Therapeutic advances in gastroenterology. Jul; 2012 5(4):219-32. PubMed PMID: 22778788. Pubmed Central PMCID: 3388523. [PubMed: 22778788]

53. Clostridium difficile-associated diarrhea can be associated with stomach acid drugs known as proton pump inhibitors (PPIs). U.S. Food and Drug Administration; 2012. [updated 02/15/1302/27/13]. Available from: http://www.fda.gov/drugs/drugsafety/ucm290510.htm

54. Mezoff E, Mann EA, Hart KW, Lindsell CJ, Cohen MB. Clostridium difficile infection and treatment in the pediatric inflammatory bowel disease population. Journal of pediatric gastroenterology and nutrition. Apr; 2011 52(4):437-41. PubMed PMID: 21407116. Pubmed Central PMCID: 3075442. [PubMed: 21407116] 